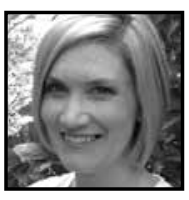

\title{
The Ups and Downs of a French Immersion Kindergarten Teacher: My Journey Toward an Inquiry-Based Approach to Teaching
}

\author{
Paula Fortier, University of Saskatchewan
}

\section{ABSTRACT}

Drawing on her lived experiences, and using the metaphor of a Snakes and Ladders game, the author reflects on her teacher practice related to using an inquiry approach in her French Immersion Kindergarten classroom. Looking backward while moving forward in time, she makes visible her process of change, foregrounding how her beliefs about children, teaching, and learning - her educational philosophy-paired with a new understanding of learning theories - in particular, constructivism - shape a pedagogical approach centered in inquiry-based learning. She stories her move from being structured and teacher-directed in her pedagogical approach to embracing an emergent curriculum and a student-centered pedagogy.

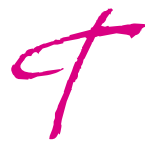

hroughout my career as a French Immersion elementary school teacher and especially over the last few years, I have truly felt that I am going through a process of change in my teaching philosophy, pedagogical approach, and practice. On occasion, I feel like the process of change I have been experiencing is much like a game of Snakes and Ladders. As in a Snakes and Ladders game, my teaching career has faced many ascents and descents. At times, I overcome new challenges or make discoveries through readings, conversations, and self-reflection which provide me the ability to climb that ladder to a new level of teaching. At other times, I find myself slipping down the snake-slides to old habits or a less student-centered curriculum that does not necessarily support my core beliefs. Up and down I go-but I do feel that somehow I end up further ahead regardless. In sharing my story of this journey of change, I am able to reflect on the process itself. 


\section{Before the Game Began}

Flashback - School Years 2005-2007

My Kindergarten classroom is a bright and welcoming place. The theme of the décor is primary colours. Many red, blue, and yellow bins are filled with different plastic toys, all sorted and tidy. There is colored paper with borders on all of my bulletin boards, boards filled with identical Kindergarten crafts made by my students. There are cheerful cartoon characters smiling back at me from the many displays - colours, days of the week, alphabet, numbers, and shapes - all with French vocabulary ready to be learned. These characters, like much in my room, are predictable-I have used these items from year to year and they appear like familiar friends. There are centers geared towards participation, for three or four students at a time, when the schedule permits it. The centers are organized this way so that students will feel safe, there will be less conflict, and students will get a turn to take part in every activity in which they are interested. My day is structured with many large group carpet-times where students listen to stories, participate in lessons which I present, and learn new vocabulary or concepts. These lessons are usually followed by opportunities to practice the new vocabulary or concept with a fun and interesting craft or worksheets we do as a class. My year is organized by monthly themes: Fall, Halloween, Transportation, Food and Health, Christmas, Winter, and so on. My students are happy, having fun, learning many new things _-including a new language — and they love school. I am happy and I love teaching! Why would I need to change anything?

When I recognized that I had in fact begun a journey of change in my pedagogical approach, I found myself pondering which came first-a change of practice or a change of philosophy? My reflection on this process of change has shown me how my beliefs about children, teaching, and learning - my educational philosophy — has paired with a new understanding of learning theories-in my case, constructivism - and has shaped a pedagogical approach centered in inquiry-based learning. As a result, my journey towards a more inquiry-based pedagogical approach has helped me as an educator to create a curriculum that is student-centered by being emergent-one co-constructed by me and my students.

\section{Buying Into the Game}

Fall 2008

I sit in the library at the hosting school looking around at the other Kindergarten and PreKindergarten teachers gathered here. We have been invited to this professional development session to deepen our understanding of the new Play and Exploration Guide introduced by 
the Saskatchewan Ministry of Education (2008). I have so many questions. How can this play-based philosophy fit in a French Immersion classroom? All this talk of inquiry and documentation - how can this be done in another language - a language to which these young children have not yet even been exposed? I just can't imagine it.

There is much talk of Loris Malaguzzi who became the inspiration behind the early childhood educational experiences in Reggio Emilia, Italy. Who is this man? I listen attentively. I learn that Malaguzzi was a primary school teacher who later went on to study psychology. While furthering his education, he also worked tirelessly with colleagues in Reggio Emilia to further his understanding of young children and how they learn. Then, he made it his mission to publicize his passionate belief in his image of the child-an image which is fundamental to the philosophy of education in Reggio Emilia, an image of children who are rich in potential, strong, powerful, and competent. In this view, the child is recognized as a person having his or her own values, who wants to be respected as a unique individual, and who embodies a curiosity and open-mindedness to all that is possible. I am nodding, feeling affirmed in my beliefs about children. However, if I believe these ideals to be true, how do they shine through in my practice?

Reflecting on my philosophy. "What works in helping children to learn?" is a question I have often pondered. I remember as a child watching my sister struggle through school when I seemed to succeed so much more easily. As a parent, I have watched my children face different challenges in their learning. This wonder about children's learning has been one of the main reasons for my choice to become a teacher and why I make an effort to be a reflective practitioner, searching for new ways to help each one of my students learn. This self-reflection has brought me to the challenge of enacting a new pedagogy and a new curriculum for myself and my students in our French Immersion Kindergarten classroom.

I am humbled to admit that, in the last 18 years of teaching, I have not until recently truly researched and questioned which learning theory and method I was using or would be best for my students' learning. I was simply teaching the way I had been taught to teach. I had been taught by traditional teachers with modernist views in structured settings. Doll (1993) describes this system of education as linear, sequential, and as an easily quantifiable ordering system, one focusing on clear beginnings and definite endings. 
Although I have always valued teaching and my students, I was feeling somewhat stagnant in my practice. After the Saskatchewan Ministry of Education developed the Play and Exploration, Early Learning Program Guide (2008), I was given numerous opportunities to rethink my current practices through professional development opportunities within my school division. I took part in everything that was offered and I was inspired by my school division's Early Learning team. I have always had a natural, positive image of children, as well as a deep respect for the culture of childhood. However, this experience-learning about how others were teaching or guiding children using Malaguzzi's inspiring example-transformed me, my teaching philosophy, and how I viewed both curriculum and my pedagogical approach to teaching and learning.

The poem, The Hundred Languages of Childhood, by Malaguzzi (Reggio kids, 2014), inspired me, and I felt that its words were sadly true. "...The school and the culture... tell the child: that work and play, reality and fiction, science and imagination, sky and earth, reason and dream, are things that do not belong together...." I also listened to Sir Ken Robinson's (2006) TEDtalk in which he stated that "schools can kill creativity" and I thought that I, too, may have been playing a part in taking the natural creativity out of our children. With this awareness, I began a new journey. Much like the excitement of opening a game box for the first time, I was filled with enthusiasm as well as some apprehension. I did not know the rules to this game; I had never played it before. Nevertheless, I was excited to learn something new, and so I rolled the dice.

\section{Getting the Game Started}

Summer 2009

I am addicted to garage sales! I am constantly searching for objects, furniture, or any unique piece to make my classroom more inspiring and inviting. I also collect items from nature: bird nests, wasp nests, sticks, pussy willows, peacock feathers, branches from anywhere and everywhere. Today, I found an old chandelier!

At the last garage sale, the woman took me into her backyard to show me what she creates in her spare time-willow trellises, tables, and chairs. "Would you be interested in these things?" she inquired. She even offered to come to school and show my students how she makes these willow creations. "Maybe they could each make a basket!" I found it interesting that simply opening myself to plan a more welcoming environment for my students and their families, in merely aspiring to have a classroom that can be the foundation of a more inclusive learning community, I was already developing relationships and finding experts to share their "funds of knowledge" (Moll, Amanti, Neff, \& González, 1992). 
Developing a new pedagogy. Changing my classroom environment was concrete, hands-on, and fun. I worked to create areas where children could be independent in their learning. I created aesthetically pleasing and inspiring spaces, gave the children more opportunity for experimenting in learning through play, and offered varied areas and time within our space and our schedule to do so. I was climbing many ladders towards my goal of a new pedagogical approach.

With this change in environment, I began to pay more attention to the total school experience and to seeing planned curricular outcomes differently. I strove to empower children and their families in concrete and authentic ways. I wanted my students' stories and experiences to drive my curriculum and for it to be attentive to the diversity in their lives. As I said before, I have always known children to be full of knowledge and naturally inclined to wonder, but I found my prior curriculum static and unsupportive of this belief. I was searching for a way to do, as Doll (1993) challenged, more than simply re-form my methods and practices, but to question the assumptions on which these methods and practices were based and to develop a new pedagogical approach to teaching and learning.

\section{Rolling a Double and Climbing Up Some Ladders}

I was then inspired by Mary Cowhey's 2006 book, Black Ants and Buddhists. I began looking for more opportunities to make connections between my students' interests and the curriculum, to broaden and deepen their learning experiences, to increase authenticity in our classroom practices, and to build bridges between school and my students' families as well as their community. I was moving from a teacher planned and taught curriculum to an emergent curriculum, one that arose out of the lives of my students. I was seeing my role as a teacher differently and my students' positioning in relation to curriculum differently as well. With this new vision, I began creating curriculum with my students, just as Cowhey so often does. This new emergent curriculum arose out of the lives and interests of my students, rather than being made for them by me alone.

My goal was to catch my students' sparks of wonder and create a fire of learning. I wanted to observe them and listen to them. I wanted to be open enough to hear their questions and recognize their interests. I wanted to use their interests and inquiries to create an environment of learning where our mandated curricular outcomes would still be achieved. However, I continued to grapple with how this could be accomplished. As in a game of Snakes and Ladders, even with a goal in mind, I found myself sliding back a few spaces. I struggled with the inclination to adhere to my old ways, to rely on the 
planned, mandated curriculum, as I tried to integrate stories from my students' lives, their wonders and their journeys into the curriculum. Facing this struggle, I felt I needed more guidance.

Prior to the decision to further my education, I had not done a lot of reading on learning theories or early childhood development. Although I had often included reading and journaling as a process through which I obtained professional development, my choice in literature tended to be professional rather than academic. I enjoyed summaries of other educators' successful practice, which I found offered motivation. However, when I was encouraged to read more academic literature in my graduate program, I recognized that rather than simply offering motivation, the academic literature provided me with the inspiration that comes from knowing the learning theory on which particular aspects of practice rest. With this new reading that related theory to practice, I found a stronger foundation on which to situate my developing understandings and choices.

Prior to expanding and deepening my choice in literature, I assumed the way I had been teaching was the way it should be done. However, with my new inspiration from the philosophies of Reggio Emilia, and from my colleagues and professors, I was learning to label or put a name to the new practices I was implementing. I found myself asking, "Why am I now drawn to a more emergent curriculum-a curriculum that is based on the students' interest and passions as well as the teacher's? Why do I feel that this emergent curriculum is better supported by a different pedagogical approach than the one I have been using-one in which inquiry is central? What do I really know about this more constructivist approach?"

\section{September 2011}

With my newfound enthusiasm I was determined to implement an inquiry-based approach to teaching and learning in my classroom. In French Immersion Kindergarten there is certain vocabulary that must be learned. Most Kindergarten-aged children know their colours in English, therefore the introduction of the French words for colours is non-threatening. I thought an inquiry-based approach to learning colours would offer a variety of interesting and engaging ways for children to use the new vocabulary in authentic situations.

Prior to beginning this journey, I would have had my students colour work sheets, play organized games, work in a type of booklet or make a craft in order for them to practice, and for me to assess, their vocabulary learning. Then, early in my journey, early in my understanding of inquiry and assessment, I would have offered a variety of opportunities to the children to use the new vocabulary during play and exploration time, such as in 
centers and classroom activities. Now, I had a different view. I felt that I better understood the complexity of children's thinking and learning. I wanted my students' experiences of learning to be deeper. This time, I slowed down, listened, and followed their lead.

Although it was my choice to introduce the colour words in French, I wanted the students to guide their own learning and they had many great suggestions. After brainstorming about what we already knew concerning colour, one student asked, "What can we make with colour?" From this wonder, the students suggested many ways that we could create with colour.

One child had an experience playing music with a coloured xylophone at home, so we inquired about creating music with colour. We set up a music exploration center with coloured drums, glasses of coloured water, and boom whackers as well as paper and markers where the children could write their own music.

Another group of children suggested working as scientists and mixing primary coloured water in vials with droppers from tubs of water. From this investigation, the children had more questions about colour shades and how to create other colours, so we experimented with a variety of paints.

The paints then triggered another wonder, "How do artists create with colour?" This wonder began a discussion about real-life art and abstract art. The students eagerly awaited opportunities to paint and use other mediums to create works of art, and we were drawn into a mini Van Gogh and Pollock art study.

The students focused on many math concepts without even knowing it. They often asked for materials of many colours for sorting, patterning, and creating.

Throughout the inquiry we had many philosophical discussions concerning colour when students wondered, "Where does colour come from?" We debated whether colours in our environment are natural or manufactured by people.

I was surprised by some social awareness that came about from this inquiry on colour when we touched on the differences in the colour of a person's skin. The children recognized through literature and through some deep discussion that some people at times make assumptions or stereotype other people because of the colour of their skin.

One child even suggested spreading joy to others by using colour when they heard of a critically ill little girl who was collecting rainbows from all over the world. 
This was just the beginning. This was just a taste of the fulfilling, complex fire of learning for which I had been searching.

A new curriculum. Keeping in mind that Schwab (1973) challenged educators to conceptualize curriculum as comprising four commonplaces of equal rank: the learners, the teachers, the subject matter, and the milieus, I thought it was important to reflect on my four curricular commonplaces. Who are my students and why are their interests and inquiries important? As a teacher, what are my biases, stereotypes, and truths that affect my interpretation of the formal curriculum? How can we work alongside each other-teachers and students - to achieve the curricular outcomes? How does teaching a second language, as in my French Immersion Kindergarten classroom, affect my curriculum and my pedagogy? How do I draw upon or how am I bound by my teaching milieus-my teaching environment, the culture of the school in which I am currently teaching, my classroom, my students and their families?

I found the term "curriculum making," used by Clandinin and Connelly (1992), as defining a teacher's active inquiry into curriculum. "This term [is] expansive, capturing an understanding of how the teacher makes curriculum alongside their students" (Ciuffetelli Parker, Pushor, \& Kitchen, 2011, p. 10). Clandinin and Connelly (1992) chose to use the term curriculum making rather than remaining with their earlier term "curriculum planning" (1988). Curriculum planning was a term which I was more familiar with because I had so often heard talk of it during my years as a teacher candidate and in my early years of teaching. I now recognize that curriculum making better defines what I want to achieve in my pedagogy. However, I also recognize that curriculum making is a more complex process because it truly is a human process and involves more than just a teacher's input. This reality can sometimes cause teachers to slide back down some snakes as they engage fully in the game. What do I bring to curriculum-making and who am I as a facilitator in the process of curriculum-making?

I continue to be moved by Cowhey (2006) as a curriculum-maker and as I continue to learn more about inquiry-based learning. I see the importance of critical thinking and the importance of teaching critical thinking skills implicitly in my classroom. Also, I see that family engagement (Pushor \& Ruitenberg, 2005) is paramount to student success, being sure to consider the learners and their milieu, not simply the teacher and the subject area. In order to educate the whole child, it is important that we become part of a community of learners that includes the family of the child. Cowhey encourages me to look critically at each and every project I undertake in order not to reinforce stereotypes, oversimplify a problem or a solution, or fail to teach children an 
understanding of a social cause. She teaches the importance of authentic lessons as well as teaching compassion and empathy, true lifelong lessons.

I understand, as Delandshere (2002) points out, that there is an essential need to reconnect our educational practices to theoretical and philosophical considerations as a means of clarifying the assumptions we make about learning and teaching. I was not sure how to accomplish this ideal until I was introduced to the idea of the critically reflective classroom through Riley and Rich (2011). The authors argue that creating such a classroom will call upon teachers to re-contextualize the school context. Critically reflective classrooms emphasize co-operation, co-learning, and the rights of the teacher, the students, and the students' families. They are places where the teachers, the students, and their families share ideas about learning, what to learn, and the ways in which to learn. It is through teachers sharing their own stories with their students, as well as listening to their students' stories with respect- "sharing stories of who we are and what matters in our worlds...stories of who we are now and who we might become" (p. 121) -that all involved in the learning process will come to fully understand critically reflective classrooms and what this type of classroom might offer.

At a recent conference, it was exciting and thought-provoking to hear the keynote speakers Elena Giacopini and Loretta Bertani from Reggio Emilia, Italy (2012) explain that the approach used in Reggio Emilia was not a method, but an experience which is tied to the values and cultural aspects of their city. The infant and toddler centers and the preschools in Reggio Emilia have approached learning in an open way, using projects that are important in the mind of all citizens of every age. They spoke of the principles of early childhood education in Reggio Emilia and of their recognition that students should not be directly taught concepts but be given opportunities to construct their own theories. These theories are encouraged to be pliable so that they can constantly be changed as the students give them meaning and collect more knowledge. They spoke of many different ways and points of access to knowledge and they explained that often education systems are asking students to repeat and regurgitate information rather than to construct and share their knowledge and understanding.

When reflecting on the traditional school systems I had come to know, I found this to be true. Doll (1993) wrote of how much of the pedagogical approach to curriculum to date has trained us to be passive receivers of preordained truths, not active creators of knowledge. I found that prior to beginning this journey towards a more emergent curriculum I had been teaching truths or facts to my students after which I was expecting them to demonstrate the accumulation of these facts. 
On the other hand, pedagogy like the one enacted in Reggio Emilia honors an individual's ability to form, plan, execute, and evaluate. It calls for a curriculum, as Doll (1993) described, that needs to be created by the classroom community, not by textbook authors. It calls for a curriculum rich in diversity, as well as a classroom atmosphere that fosters exploration. As I worked to define the learning theories for myself, I found that these ideals aligned with what I understood to be a constructivist approach to teaching young children.

Because constructivism views learning as a process in which the learner actively constructs or builds new ideas or concepts, it can be assumed that inquiry-based learning as a pedagogical approach arises out of the theory of constructivism. Constructivists believe that the learners construct their own knowledge and this knowledge is not set apart from the experiences of the learner or the community of learners. Tobias and Duffy (2009) cite constructivist authors who argue that "knowledge is situated in the activity of the learner and is a product of that activity and the context and culture in which it occurs" (p. 3).

Although I recognize that my identity clearly supports a more constructivist approach to teaching, it also seems that many educators have occasions to find themselves, like myself, struggling to define and to apply a particular approach. At times we are climbing ladders and, at times, sliding down snakes.

\section{Sliding Down Some Snakes and Learning Some Lessons}

February 2013

While working on inquiry with my students, I very much wanted the ideas and the wonders to come from the students. I was cautious to step back, wait patiently, and listen to hear their questions and discussions, to see where the next wonder would lead us. I found it very difficult not to answer their questions right away. I bit my tongue and wondered with them, even if the answer was obvious to me.

At times the conversations just would not happen. The interest was not there. One example of this occurred during an inquiry study into the Northern lights. One day, after a long weekend in February, one of my students came to school excited to share an experience he had at his cabin in northern Saskatchewan. As he stood in front of the class, his excitement was contagious! He told us all about "the dancing lights in the night sky" and the other students were mesmerized. At the time, I was apprehensive. Did we really want to learn about the Northern lights in Kindergarten? How would I describe the 
science behind the lights if I did not really understand it myself? Is aurore boréale and its surrounding vocabulary worth learning in French at this age? I was not sure how to respond or how to scaffold this excitement. Should I just let it pass? Should I let them figure it out in their own way? Although I ideally want to catch my students' sparks of wonder and create many opportunities for discovery, I found it is not always a simple process and my role as a facilitator in their learning is not always clear.

When we decided to go ahead and learn about the Northern lights, the results of this inquiry were amazing! We learned so many interesting things and chose many fascinating ways to represent our learning with plasticine, watercolour paints, tissue paper, food colouring, and the light table. The children in this particular group were so excited that I wanted both my Kindergarten groups to have the same experience. However, when I introduced the Northern lights idea to my other Kindergarten class and provided them the same materials and mediums with which to create, they were not interested in the same way. There was some curiosity on the topic but not nearly the same amount as the group who had been inspired by one of their peers. This was a clear example to me of the influence of the learning on the group when the curriculum came from the students' interests. It was an example of the importance of being open to an emergent curriculum in my practice and the power that comes from using an inquiry approach in my pedagogy.

What is inquiry? Initially in my practice, I had not put the focus on defining inquiry. As I began to research further, I was struck by the debate among educators and philosophers. One group of authors explains that "if inquiry is to continue to be useful, educators will have to press for clarity when the word enters a conversation and not assume they know the intended meaning" (Blanchard et al., 2010, p. 581). Up until then, I had definitely been making that assumption. The readings and discussions I have been having since that awakening have required me to define the term inquiry more specifically. The Merriam Webster dictionary (2013) simply defines inquiry as "a request for information." While listening to the conversations of my graduate classmates and my colleagues at school, I found that inquiry, as a method of instruction, was defined in a variety of ways: open but guided learning, student ownership over the process of learning, teachers and students taking risks, teachers encouraging the representation of learning in creative ways, more authentic and meaningful subject matter for a specific group of students, teacher as facilitator or guide, the importance of the process over the end-result, more focused and engaged students, among others. I found myself in agreement with all of these definitions but overwhelmed with the broad spectrum they seemed to cover. 
I was comforted by the more comprehensive definition of inquiry given by Blanchard et al. (2010). The authors define levels of inquiry based on the descriptions of Abrams et al. (2007), which focuses on the goal one has for the inquiry and the instructional approach one uses to engage students-starting at traditional "verification" and moving to "structured," "guided" and "open" inquiry (as cited in Blanchard et al., 2010, p. 581). Blanchard and colleagues (2010) explain that these designations may not always be clear-cut and that the optimal level of inquiry will vary according to the classroom context, individual students and, of course, the topic of inquiry. I found these descriptors supported my teaching and my view that all children and groups of children are unique in their learning. If teachers work to treat their students as the unique individuals that they are, they will be working toward the goal of an optimal learning environment.

I recognize there is not any one pedagogical approach that will satisfy every learner. More than that, I recognize it is ideal to use a variety of methods based on the concept and the context. Cobb (1996) describes a common theme I found in much of the literature I have read, the idea that coordinating perspectives can be developed while addressing all students' needs. He explains that teachers who act with wisdom and judgment are continually developing ways to cope with particular situations. Just as the research of Blanchard et al. (2010) documents the relative effectiveness of various levels of inquiry methods, the authors also suggest that it is important for teachers to understand that there is no singular "holy grail" of inquiry (Settlage, 2007, as cited in Blanchard et al., 2010). They remind us that teacher judgment is required to understand the optimal inquiry approach to use in any classroom context.

\section{Getting Close to the Top of the Game Board}

Spring 2013

Who would have thought that the death of a classroom pet would bring about such an opportunity for learning? Our classroom had three well-loved pets: a bearded dragon named Spike, a corn snake named Lucky, and a spotted gecko named Lillian. When Lillian was found dead one morning, it caused quite a stir. "Why did she die? Did we not take good enough care of her? Was she sick? Are we caring for our pets properly?" Whew! Most of these questions left me feeling guilty, inadequate, and uncomfortable.

I had, however, just finished a course offered through the Saskatchewan Teachers' Federation called "Responding to Children's Interests." After the course, I had decided to really focus on teaching using an inquiry-based approach to achieve my curricular outcomes. I found one of the hardest parts of teaching using inquiry was the change in how a concept 
is taught, or even which concept is explored, because it depends on the needs of the students rather than what I have decided - a new sense of curriculum - an emergent sense.

At this point in time, I was no longer teaching by themes, following my year-at-a-glance, or making all the decisions regarding my students' learning. I was working to consider my students as co-authors and not reverting back to the old power structures of a modernist classroom. I was also working to create a home-away-from-home atmosphere in my classroom and create open, trustful connections that empower students to participate actively and responsibly in their learning. I did a lot of brainstorming with the students and I always wrote down everyone's ideas and questions without judgment. This was not always easy. I had to work to see myself more as mediator of learning alongside my students, and of an individual who was working to build a true learning community. I was no longer the keeper of the knowledge.

With all this in mind, I embarked on a learning journey with my students for which I was not at all prepared. I did not have books or supplies that would support a unit of study on reptiles. I did not even know that much about reptiles. I had acquired all my classroom pets from others who could no longer care for them and, up until Lillian's death, I had simply followed the instructions left by their previous owners. Now, this topic was something all my students were interested in and inquiring about. It was authentic.

I started by writing down all their questions, then by separating them into similar groups. We decided, after some discussion, that what we really wanted to know was how to properly care for the reptiles in our school. We divided into groups of interest-some chose to study Spike the bearded dragon, some Lucky the snake, and some Leo the red-eared slider turtle that lived in the preschool room. My challenge was first to choose vocabulary that my students would focus on in French-reptiles had never been on my list of vocabulary to cover in French Immersion Kindergarten. Next, I needed to support their search for knowledge. How would we best find answers to their questions? We borrowed books, we used the SMARTboard to make searches on Google, and we invited experts to share their knowledge. We represented our learning in drawings, clay-making, and paintings. In our search for answers, we learned about others' ways-of-knowing while reading First Nation legends about reptiles AND, throughout all of this study, I was no longer the only person speaking French in my classroom. My students were so enthusiastic about my engagement in their inquiry and their play that they were eager to use the new vocabulary I had introduced to them.

I recognized that when the demonstration of skill-such as using new French vocabulary-was experienced in an authentic situation and in context with my students' 
interests, they were far more able to remember and use the vocabulary in authentic ways. My focus was more on the process of learning and the ongoing learning that was happening rather than simply the end result. Yet our end result was wonderful! We ended up presenting a learning expo on reptiles to our families and school community and we covered many of the curricular outcomes along the way.

This experience was driven by the students, yet I could have easily missed the opportunity. Did the students do it all on their own? Of course not! It was a lot of work on my part but the risk and the work was worth it!

A new pedagogical approach. I have gained much freedom within knowledge and self-reflection. Riley and Rich (2011) explored "curriculum as a story that unfolds and helps us to understand who we might become as teachers, co-learners and as human beings" (as cited in Stanley \& Young, 2011, p. 101). I feel that reflecting on my lived experiences is an important step in understanding and creating a new philosophy of education. While I think my main goal in the initial stages of my teaching career was for learning to be fun, I have now climbed ladders to a place of new understanding and expectations for my students. I now desire deep learning and understanding, critical thinking, authentic engagement-so much more than fun.

However, there are still more ladders for me to climb and some snake-slides to slip down. Just as Clandinin and Connelly (2000) describe a philosophy of education based on a foundation of lived experiences with a focus on shared narrative, I make efforts to share my lived experiences and be open to the narratives surrounding me, but I also feel that I am still learning. While reading the children's book Dream by Susan Bosak, a quote by Friedrich Nietzsche heartened me. He stated that one "who would learn to fly one day must first learn to stand and walk and run and climb and dance; one cannot fly into flying" (as cited in Bosak, 2004, n.p.). At times throughout this journey, I felt I was crawling or walking or dancing. Other times I felt I was standing still and, recently, there have finally been times when I felt I was flying. Throughout this learning, I worked to remember that this journey of change has been like playing a board game and it has taken patience to roll the dice and move forward a few squares at a time. I have now shared part of my story-my questions, challenges, and celebrations. I recognize that through a renewed philosophy, the development of a new pedagogical approach, the co-creation of an emergent curriculum, and the implementation of many new practices, I continue to question who I might become as an educator and I look forward to the future. 


\section{References}

Bosak, S.V. (2004). Dream. Whitchurch-Stouffville, ON: TCP Press.

Blanchard, M. R., Southerland, S. A., Osborne, J. W., Sampson, V. D., Annetta, L. A., \& Granger, E. M. (2010). Is Inquiry possible in light of accountability?: A quantitative comparison of the relative effectiveness of guided inquiry and verification laboratory instruction. Science Education, 94(4), 577-616.

Ciuffetelli Parker, D., Pushor, D., \& Kitchen, J. (2011). Narrative inquiry, curriculum making, and teacher education. In J. Kitchen, D. Ciuffetelli Parker, and D. Pushor (Eds.), Narrative inquiries into curriculum making in teacher education (pp. 3-18). Bingley, UK: Emerald Group Publishing.

Clandinin, D. J., \& Connelly, F. M. (1988). Teachers as curriculum planners: Narratives of experience. New York: Teachers College Press.

Clandinin, D. J., \& Connelly, F. M. (1992). Teacher as curriculum maker. In P. Jackson (Ed.). Handbook of curriculum. (pp. 363-461). New York: Macmillan.

Clandinin, D. J., \& Connelly, F. M. (2000). Narrative inquiry: Experience and story in qualitative research. San Francisco: Jossey-Bass Publishers.

Cobb, P. (1996). Where is the mind? Constructivist and social constructivist perspectives on mathematical development. Educational Researcher, 23(7), 13-20.

Cowhey, M. (2006). Black ants and Buddhists. Portland, MN: Stenhouse Publishers.

Delandshere, G. (2002). Assessment as inquiry. Teachers College Record, 104(7), 1461-1484.

Doll, W. E. (1993). A post-modern perspective on curriculum. New York: Teachers College Press.

Inquiry [Def. 2]. (n.d.). In Merriam Webster Online, Retrieved from: http://www.merriam-web ster.com/dictionary/inquiry.
Moll, L., Amanti, C., Neff, D., \& Gonzalez, N. (1992). Funds of knowledge for teaching: Using a qualitative approach to connect homes and classrooms. Theory Into Practice, 31(2), 132-141.

Nietzsche, F. (n.d.). BrainyQuote.com. Retrieved from: http://www.brainyquote.com/quotes/ quotes/f/friedrichn159166.html

Pushor, D., \& Ruitenberg, C. with co-researchers from Princess Alexandra School. (2005). Parent engagement and leadership. Research report, project \#134, Dr. Stirling McDowell Foundation for Research into Teaching, Saskatoon, SK, 79pp. Retrieved from: http:// www.mcdowellfoundation.ca/main mcdowell/projects/research_rep/134_ parent_engagement.pdf.

Reggio kids (2014, May 2). Loris Malaguzzi's poem The hundred languages of childhood. [Web log post]. Retrieved from http://www. reggiokids.com/about/hundred-languages. php

Riley, T., \& Rich, S. (2011). No more boundaries: Narrative pedagogies. Curriculum and imagining who we might be. In D. Stanley \& K. Young (Eds.), Contemporary studies in Canadian curriculum: Principles, portraits, and practices (pp. 101-123). Calgary: Detselig Press.

Robinson, Sir K. (2006, February). How schools kill creativity. [video on TED.com.] Retrieved from http://www.ted.com/talks/ken_robin son_says_schools_kill_creativity

Saskatchewan Ministry of Education. (2008). Play and exploration, early learning program guide. Regina, SK: Ministry of Education.

Schwab, J.J. (1973). The practical: Translation into curriculum. School Review, 81, 501-522.

Tobias, S., \& Duffy, T. M. (2009). The success or failure of constructivist instruction: An introduction. In S. Tobias \& T. M. Duffy (Eds.), Constructivist instruction: Success or failure? (pp. 3-10). New York: Routledge. 


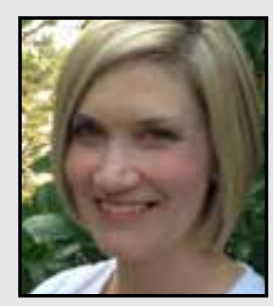

Paula Fortier has been a French Immersion educator for almost 20 years. She currently teaches Kindergarten with the Greater Saskatoon Catholic Schools in Saskatoon, SK where she lives with her family. She graduated from the University of Regina with a Bachelor of Education and recently completed a Master's degree in Curriculum Studies with a focus on Early Childhood Education at the University of Saskatchewan. Her passion resides in children of all ages but she has an exceptional love and respect for early childhood and second language education. 